\title{
An evaluation of range accuracy in the Super Dual Auroral Radar Network over-the-horizon HF radar systems
}

\author{
T. K. Yeoman, D. M. Wright, A. J. Stocker, and T. B. Jones \\ Department of Physics and Astronomy, Unıversity of Leicester, Leicester, England, United Kingdom
}

\begin{abstract}
The Super Dual Auroral Radar Network (SuperDARN) of over-the-horizon HF radars forms a powerful diagnostic of large-scale ionospheric and magnetospheric dynamics in the Northern and Southern Hemispheres. Currently, the ground location of the HF radar returns is routinely determined by a simple range-finding algorithm, which takes no account of the prevailing $\mathrm{HF}$ propagation conditions. This is in spite of the fact that both direct $\mathrm{E}$ and $\mathrm{F}$ region backscatter and $1 \frac{1}{1} 2$-hop $\mathrm{E}$ and $\mathrm{F}$ region backscatter are commonly used in geophysical interpretation of the data. Here HF radar backscatter which has been artificially induced by the high-power RF facility (ionospheric heater) operated by the European Incoherent Scatter Scientific Association at Troms $\emptyset$ is used to provide a range calibration for the SuperDARN radars. The known ground range, the measured radar slant range, and the group path calculated by a ray-tracing simulation are compared. The standard algorithm for backscatter ground range location is found to be accurate to within 16 $\mathrm{km}$ and $60 \mathrm{~km}$ for direct and $1 \frac{1 / 2}{2}$-hop backscatter, respectively.
\end{abstract}

\section{Introduction}

The SuperDARN network [Greenwald et al., 1995] currently consists of eight over-the-horizon HF radars in the northern polar regions and six radars in the southern polar regions. Radars of this design have been in operation since the deployment of the prototype Goose Bay radar in the early 1980 s and currently form a powerful diagnostic of large-scale ionospheric and magnetospheric dynamics in the Northern and Southern Hemispheres. The radars are frequency-agile, operating between 8 and $20 \mathrm{MHz}$, and have fields of view which extend in range from $180 \mathrm{~km}$ to over $3000 \mathrm{~km}$ in standard operations. The radar systems rely on the refraction of the $\mathrm{HF}$ radiation both in order to achieve orthogonality to the Earth's magnetic field, a requirement for scattering off the ionospheric irregularities, which form the targets for such radar systems, and to achieve backscatter from the longer ranges, which require overthe-horizon operations. The ground locations of the $\mathrm{HF}$ radar returns are routinely determined by a simple rangefinding algorithm, which assumes straight line

Copyright 2001 by the American Geophysical Union.

Paper number 2000RS002558.

0048-6604/01/2000RS002558\$11.00 propagation at the speed of light from the radar site to a target at a given altitude above the Earth and thus takes no direct account of the prevailing HF propagation conditions [Baker et al., 1986]. In reality these propagation conditions are highly variable, with direct ( $1 / 2$-hop) propagation to $E$ and $F$ region ionospheric irregularities and $1 \frac{1}{2}$-hop propagation to both the $E$ and F region commonly observed by the radar systems. Previous studies have adopted a ray-tracing simulation [Villain et al., 1984; Baker et al., 1986] or velocity field cross-correlation [Ruohoniemi et al., 1987; André et al., 1997] approach to assess the accuracy of range-finding using the straight line approximation. These studies suggested agreement between the ground range and radar range within $\sim 15 \mathrm{~km}$ over a 1/2-hop path.

Early studies with HF radars either used HF radar data alone or combined HF radar data with data from instruments such as ground magnetometers, which had a limited spatial resolution and are often only available from arrays which are sparsely populated in comparison to radar fields of view. However, the growing importance of combined ground-spacecraft measurements and multi-instrument studies from the ground have led to numerous coordinated studies with instruments of a high spatial resolution, such as meridian scanning photometers, all sky cameras, and auroral imagers. In these studies the location of the radar 
Table 1. Geographic Locations of the Instrumentation

\begin{tabular}{lcc}
\hline \multirow{2}{*}{ Instrument } & \multicolumn{2}{c}{ Ground Location } \\
\cline { 2 - 3 } & Latitude, ${ }^{\circ} \mathrm{N}$ & Longitude, ${ }^{\circ} \mathrm{E}$ \\
\hline Pykkvibar & 63.77 & 20.54 \\
Hankasalmi & 62.32 & -26.61 \\
Troms Heater (field & 69.20 & 19.2 \\
$\quad$ aligned, 210 km) & & \\
\hline
\end{tabular}

backscatter is a crucial element in the study. In addition, spacecraft overpasses, where the magnetic conjugate points are computed to a high precision using geomagnetic field models, require high accuracy in the location of the $\mathrm{HF}$ radar backscatter. A illustrative example is found in the recent studies made of the footprint of the magnetospheric cusp. Optical signatures associated with dayside reconnection have been extensively investigated from the ground in the visible wavelengths of $630.0 \mathrm{~nm}$ and $557.7 \mathrm{~nm}$ associated with auroral activity [e.g. Lockwood et al., 1993, 1995; Sandholt et al., 1996]. HF radars observe pulsed ionospheric flows in the cusp region, which are the response to this transient reconnection at the magnetopause [e.g. Pinnock et al., 1993, 1995; Provan et al., 1998, 1999]. Such events have been studied in detail by a variety of instruments [see e.g. Milan et al., 2000; Neudegg et al., 1999, and references therein]. The interpretation of such studies requires an accurate evaluation of radar range, in a situation where the radar backscatter may be either $1 / 2$ hop or $1 \frac{1 / 2}{2}$ hop [Milan et al. 1998].

In this paper, HF radar backscatter which has been artificially induced at a precisely known location by the high-power RF facility (ionospheric heater) operated by the European Incoherent Scatter (EISCAT) Scientific Association at Troms $\emptyset$ is used to provide a range calibration for the Super Dual Auroral Radar Network (SuperDARN) radars. The known ground range, the measured radar slant range, and the group path calculated from a ray-tracing simulation are compared. This demonstrates an excellent agreement between the measured radar slant range and the calculated group path and allows the quantification of the deduced range accuracy to be made for $1 / 2^{-}, 1 \frac{1 / 2^{-}}{}$and $2 \frac{1}{2^{2} \text {-hop }}$ backscatter modes over paths of $\sim 850$ and $\sim 1800 \mathrm{~km}$.

\section{Instrumentation}

The data presented here result from the generation of artificial ionospheric HF coherent backscatter. It is well known that the EISCAT heating facility at Tromsø, Norway [Rietveld et al., 1993], is capable of generating artificial field-aligned irregularities using high-power HF radio waves [e.g., Robinson, 1989]. These irregularities are detectable by both incoherent and coherent scatter radars [e.g., Robinson et al., 1997]. The Co-operative U.K. Twin Located Auroral Sounding System (CUTLASS) radar is a pair of HF coherent backscatter radar systems located at Hankasalmi, Finland, and Pykkvibær, Iceland, and forms part of the SuperDARN array. Details of SuperDARN are given by Greenwald et al. [1995] and details of the CUTLASS systems at Hankasalmi and Pykkvibær are given by Milan et al. [1997]. The CUTLASS radars' locations and the Tromsø heater's ionospheric interaction location are given in Table 1 and shown in geographic coordinates in Figure 1a. CUTLASS is ideally situated for making observations of the heated volume over Troms $\varnothing$ [e.g., Bond et al., 1997; Eglitis et al., 1998], as shown schematically in Figure $1 \mathrm{~b}$.

Here data are presented from the Observations of ULF waves with CUTLASS and the Heater (SP-UK-OUCH; Wright and Yeoman [1999]) experiment. In this experiment the CUTLASS radars run in a high-temporalresolution and high-spatial-resolution mode, with Hankasalmi running a six-beam scan (scanning beams 7 through 2 , inclusive) with an integration time of $1 \mathrm{~s}$, while Pykkvibær runs a three-beam scan (beams 13-15) with a $2 \mathrm{~s}$ integration period. Thus both radars produce data with a temporal resolution of $6 \mathrm{~s}$. Both run in a high-spatial-resolution mode, with each radar having 75 range gates of $15 \mathrm{~km}$ length, centered on the heated volume at Troms $\varnothing$ (the distance to the first range gate being set at 480 and $1470 \mathrm{~km}$ for the Hankasalmi and Pykkvibær radars, respectively). The EISCAT heater was in continuous operation at 50\% power (using $6 \times 80$ $\mathrm{kW}$ transmitters, an Effective Radiated Power (ERP) of $\sim 130 \mathrm{MW}$ ), at a frequency of $\approx 4-5 \mathrm{MHz}$ for 4 hour intervals. Observations with the heater aligned along the magnetic field and employing a $\pm 30^{\circ}$ beam swing at a frequency of $1 \mathrm{~Hz}$, centered vertically, have been recorded, with the resulting backscatter detected by both radars of the CUTLASS system. The heater produces artificial electron density irregularities in the $F$ region ionosphere, which act as targets for the HF radar. The artificial targets result in very high returned backscatter power in comparison to naturally occurring irregularities. This allows a short integration time to be run on the radar, providing higher time resolution than is normally available. 
(a)

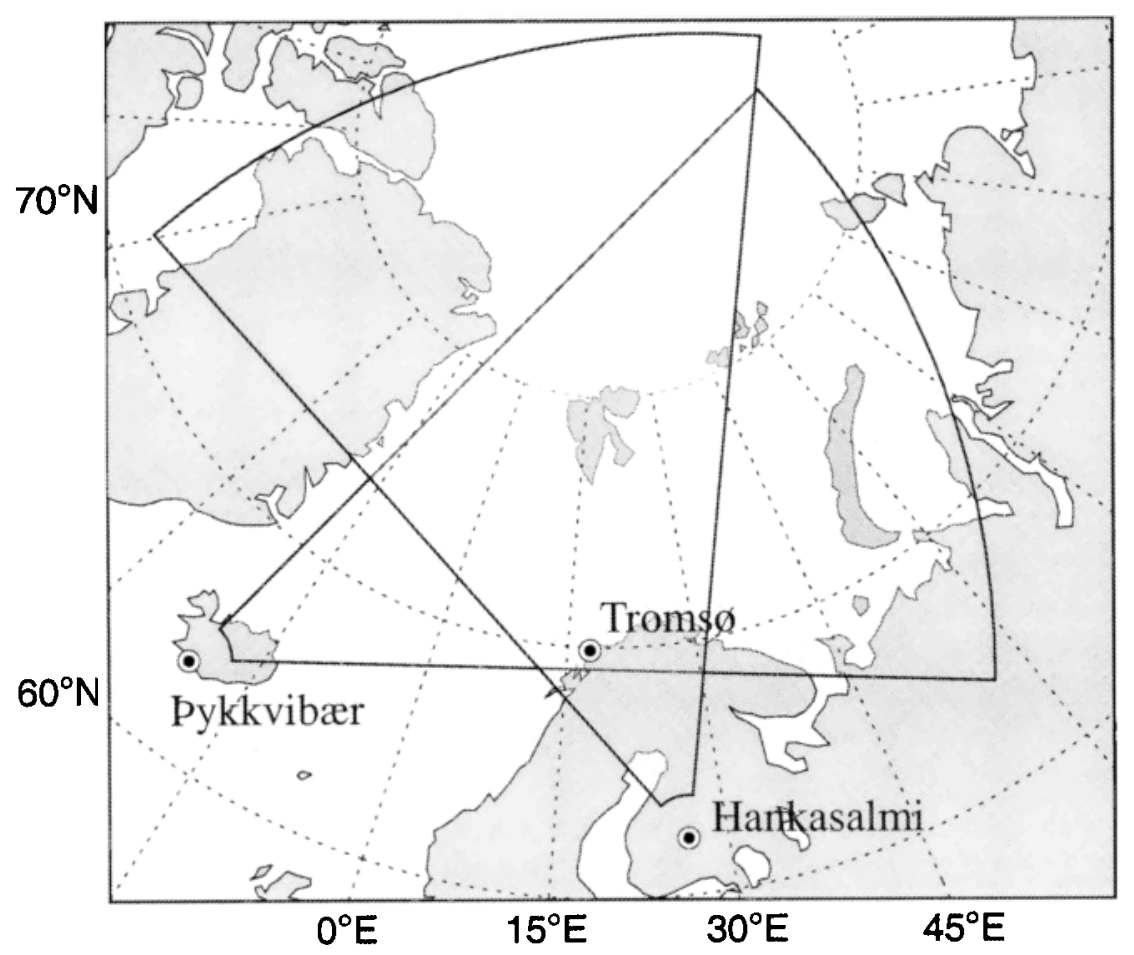

(b)

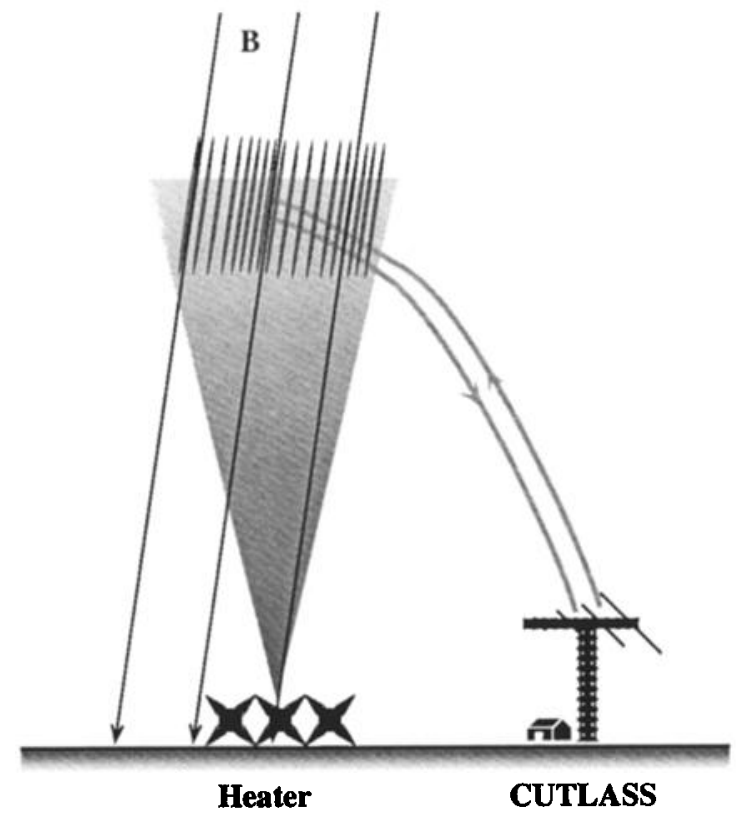

Figure 1. (a) The geographic locations of the Troms $\varnothing$ heater, and the fields of view of the CUTLASS Hankasalmi and Pykkvibær radars. (b) A schematic of the artificial backscatter experiment, SP-UK-OUCH. The Troms $\varnothing$ heater continuously heats the $F$ region ionosphere, creating artificial ionospheric irregularities. These are detected by the CUTLASS radars, operating in a high temporal and spatial resolution mode. 


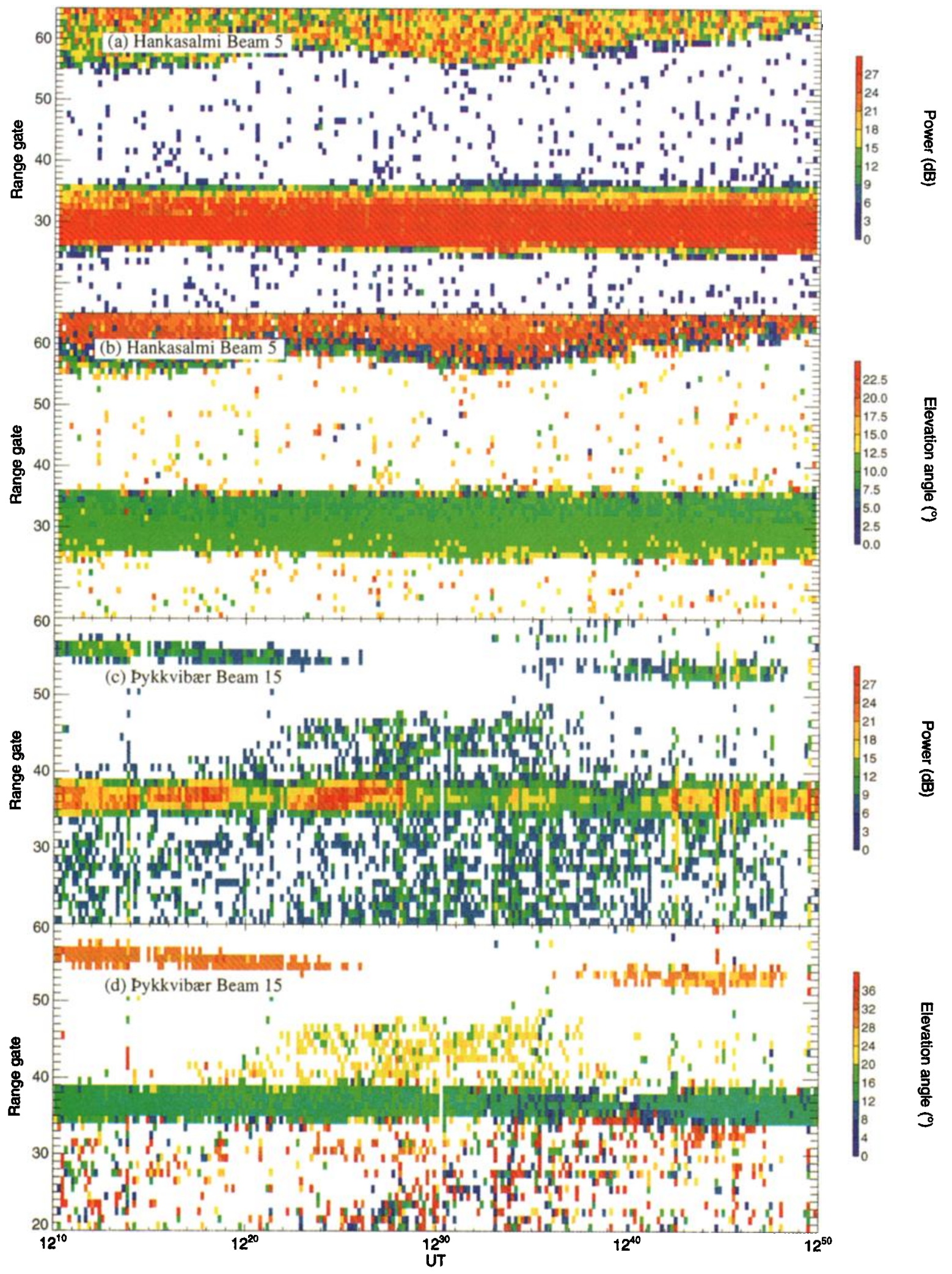

Plate 1. Artificial backscatter generated in the Hankasalmi and Pykkvibær radars during the SP-UK-OUCH run of 1210-1250 UT, October 15, 1998, as a function of time and radar range gate. (a) Hankasalmi power, (b) Hankasalmi elevation angle, (c) Pykkvibær power, and (d) Pykkvibær elevation angle. 


\section{Observations}

\subsection{SP-UK-OUCH Data}

Approximately 40 hours of the SP-UK-OUCH experiment have been run on the EISCAT ionospheric heating facility during 1998 and 1999 . Ionospheric conditions are not always suitable for heating, however, and the radar modes run are also not always suitable for statistical analysis. Here we present data from 21 hours and $30 \mathrm{~min}$ of Hankasalmi radar backscatter and 12 hours and $40 \mathrm{~min}$ of Pykkvibær radar backscatter for which strong radar returns were obtained over a number of radar range gates for periods of greater than 1 hour. In addition to strong returns we also require that the radar was operating consistently at one sounding frequency. Data from an example run of SP-UK-OUCH will be presented in detail, along with statistical analysis of the entire data set, from both radar systems.

Plate 1 presents data from a section of an SP-UKOUCH run from 1210 to 1250 UT on October 15, 1998, an interval when the heater was operating in its beam swinging mode. Returned backscatter power and elevation angle are plotted as a function of time and range gate for the Hankasalmi radar beam 5 (Plates la and $1 \mathrm{~b}$ ) and Pykkvibær radar beam 15 (Plates $1 \mathrm{c}$ and $1 \mathrm{~d}$ ) which overlie the heater location. During this interval the Hankasalmi radar was operating between 19.415 and $19.680 \mathrm{MHz}$, and the Pykkvibær radar was operating bètween 12.105 and $12.235 \mathrm{MHz}$, both frequency bands having been selected at the beginning of the experiment to optimize the returned backscatter power. In Plate la a broad band of high-power radar returns, generated by the Troms $\varnothing$ heater, can be seen between range gates 25 and 35. Lower power backscatter is also visible beyond range gate 50 , but these data have been identified by the radar, via their Doppler velocity and spectral width, as ground scatter: radiowaves that have refracted in the ionosphere and backscattered from the ground. The elevation angles for the heater-induced scatter (Plate 1b) are centered at $10^{\circ}$, with the nearer ranges exhibiting slightly higher elevation angles than the farther ranges, as expected for a constant irregularity height. The backscattered power from Pykkvibær is displayed in Plate 1c. In this case a threshold of $6 \mathrm{~dB}$ has been applied to the data, in order to reduce clutter from lowpower ground backscatter returns. Again, a band of high backscatter power is visible, this time between range gates 33 and 38. The Pykkvibær data for this interval are not as clear as the Hankasalmi data, and the unstructured low-power returns surrounding the artificial backscatter region are due to ground scatter. A second structured region of backscatter is visible centered on range gate 56. The elevation angles for the two structured regions of backscatter (Plate 1d) are centered on $18^{\circ}$ and $31^{\circ}$ for the nearer range and farther range regions, respectively. The origins of these two regions of backscatter will be discussed below in Sections 4.2 and 4.3.

\subsection{Hankasalmi Radar Performance}

In order to assess the performance of the radar system range evaluation the data from the interval presented in Section 3.1 and the overall SP-UK-OUCH data set from beam 5 of Hankasalmi and beam 15 of Pykkvibær require a more statistical analysis. In order to assess the overall performance and consistency of the radars the occurrence of backscatter with a power of $>10 \mathrm{~dB}$ has been quantified as a function of the geographic latitude and longitude determined by the radar range-finding algorithm. Figure 2 presents the results of such an analysis for the Hankasalmi radar. The occurrence of radar backscatter at power levels above $10 \mathrm{~dB}$ is plotted as a function of geographic latitude derived from the standard radar rangefinding algorithm, with occurrence denoted on the left hand $y$ axis labels. Also plotted is the actual latitude of the Troms $\varnothing$ field line as a function of altitude, denoted on the right hand $y$ axis labels, taking into account the dip angle of the geomagnetic field. Figure 2a presents the Hankasalmi radar occurrence statistics for the interval displayed in Plate 1. The region of high-power artificial scatter occupies a broad latitude range (as determined by the standard range finding algorithm) between $68.5^{\circ} \mathrm{N}$ and $70^{\circ}$. In this case the range-finding algorithm is used with a fixed height of $210 \mathrm{~km}$, which is an estimate of the heater interaction height (the upper hybrid height, which lies between the X- and O-mode reflection heights, Robinson [1989]), as determined from the heater frequency and measurements from the EISCAT dynasonde at Troms $\varnothing$. It is informative to compare such occurrence statistics with similar experiments run with a field-aligned heater. Such an experiment was run on October 18 1999, with the Hankasalmi radar again operating at $19 \mathrm{MHz}$, and is displayed in Figure 2b. The field-aligned results show a narrower band of artificial backscatter, as expected, with the center of the region lying at $69.1^{\circ} \mathrm{N}$. Results from the Hankasalmi radar are, in fact, highly consistent, and the entire data set is plotted in Figure 2c, again showing a peak occurrence at $69.1^{\circ} \mathrm{N}$, where almost 7000 data points have been accumulated. The width of the distribution in latitude in this case is some $30 \%$ larger than that in the case study patch width presented in Figure $2 b$. 

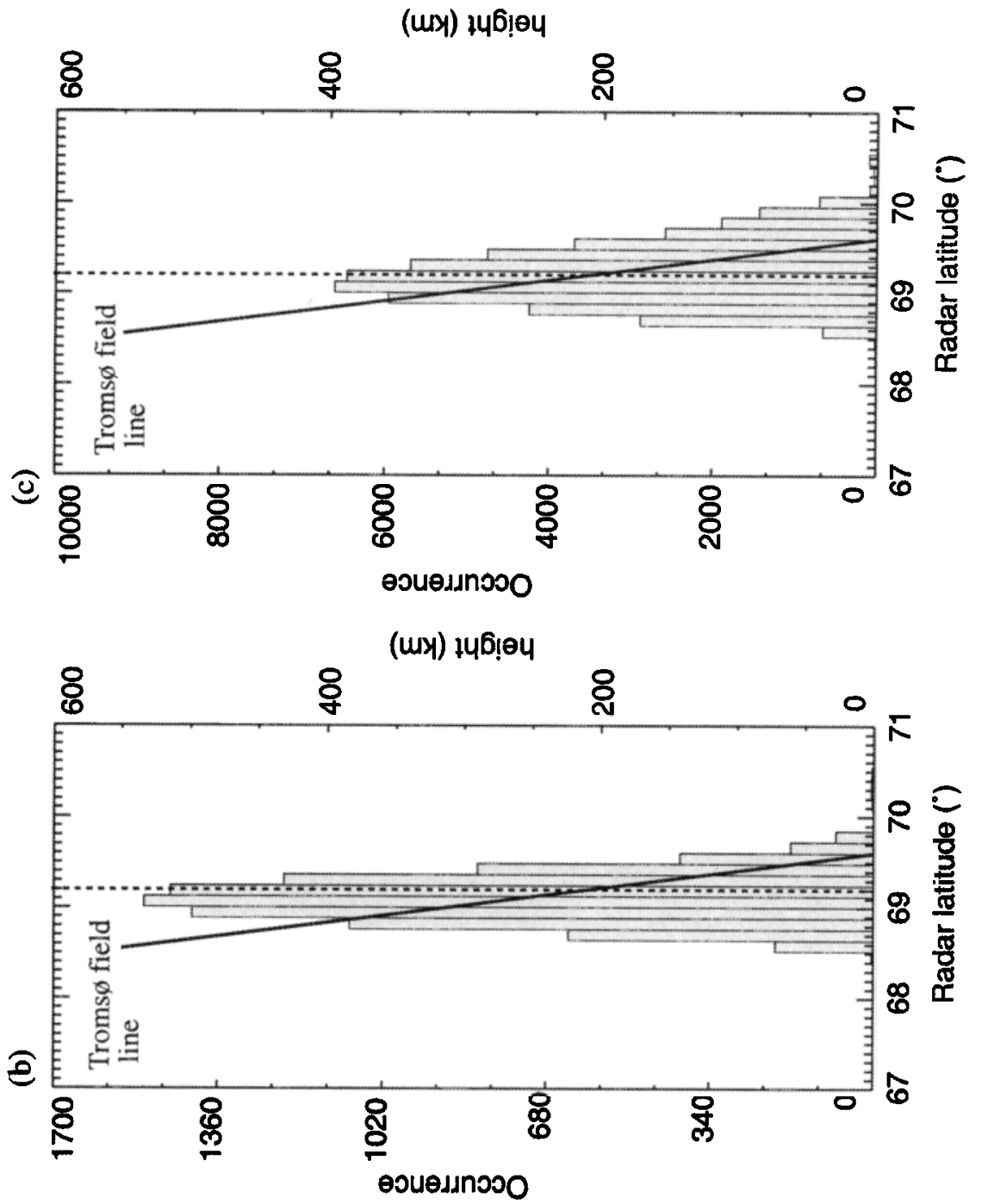

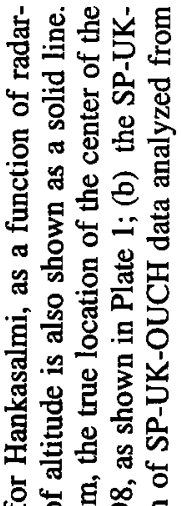

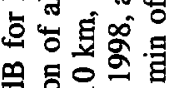

욱 등응

은ํำ

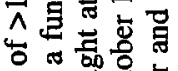

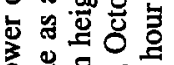

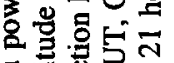

क्ञ

굴

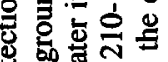
可

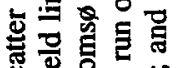

记

행응

可

递

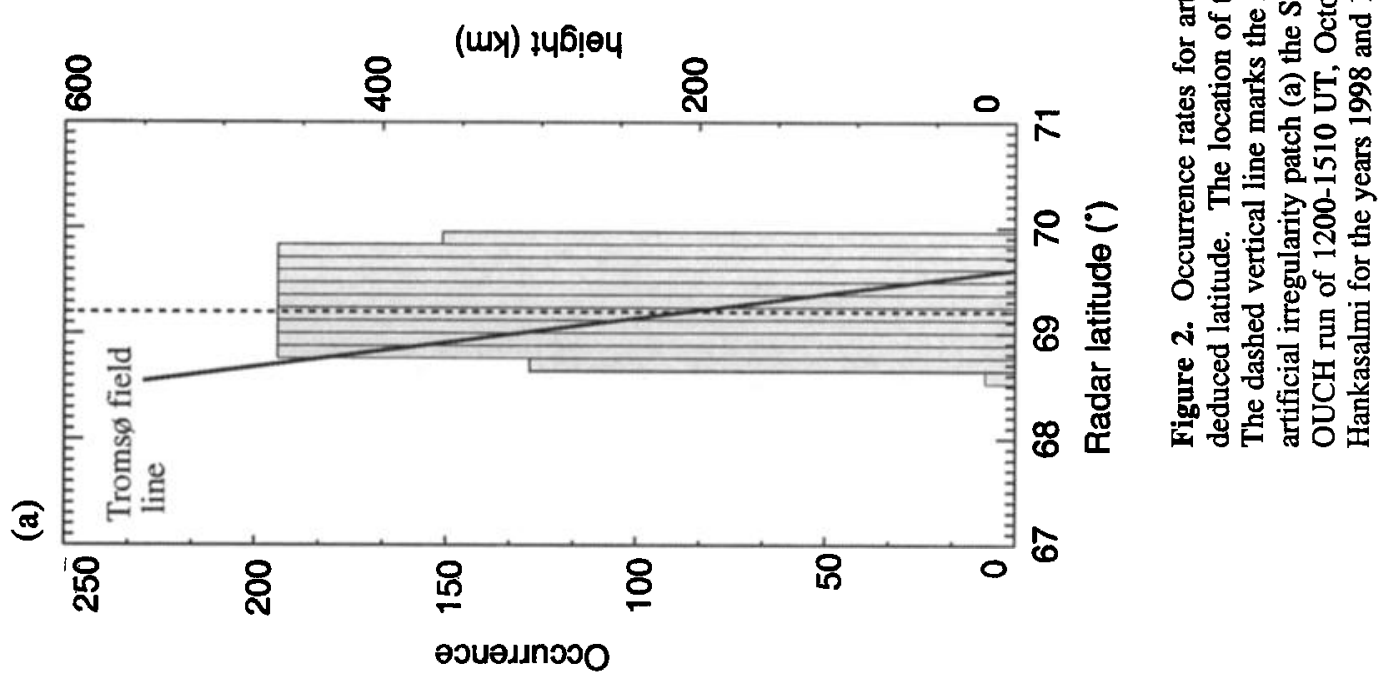


(a)

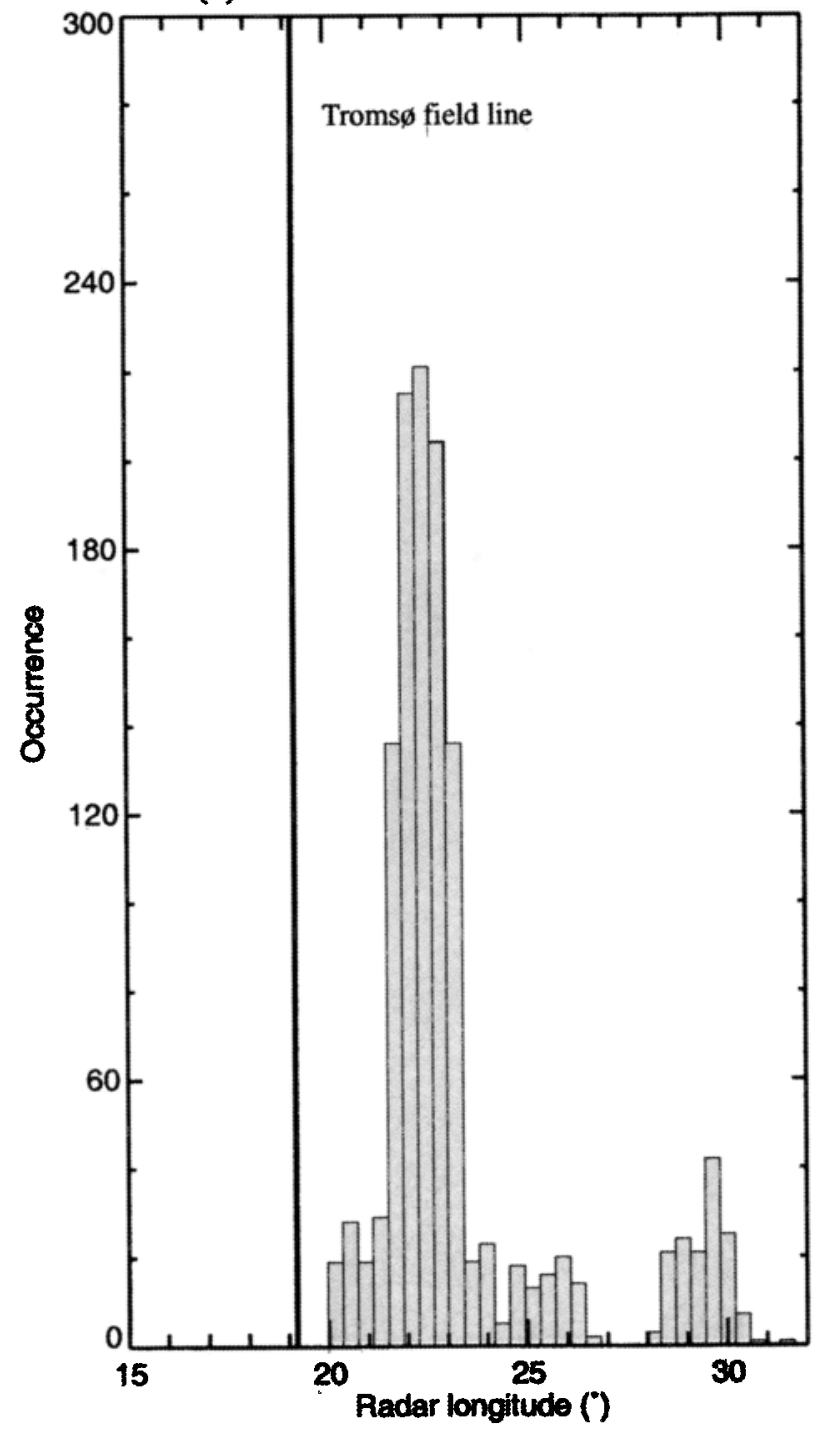

(b)

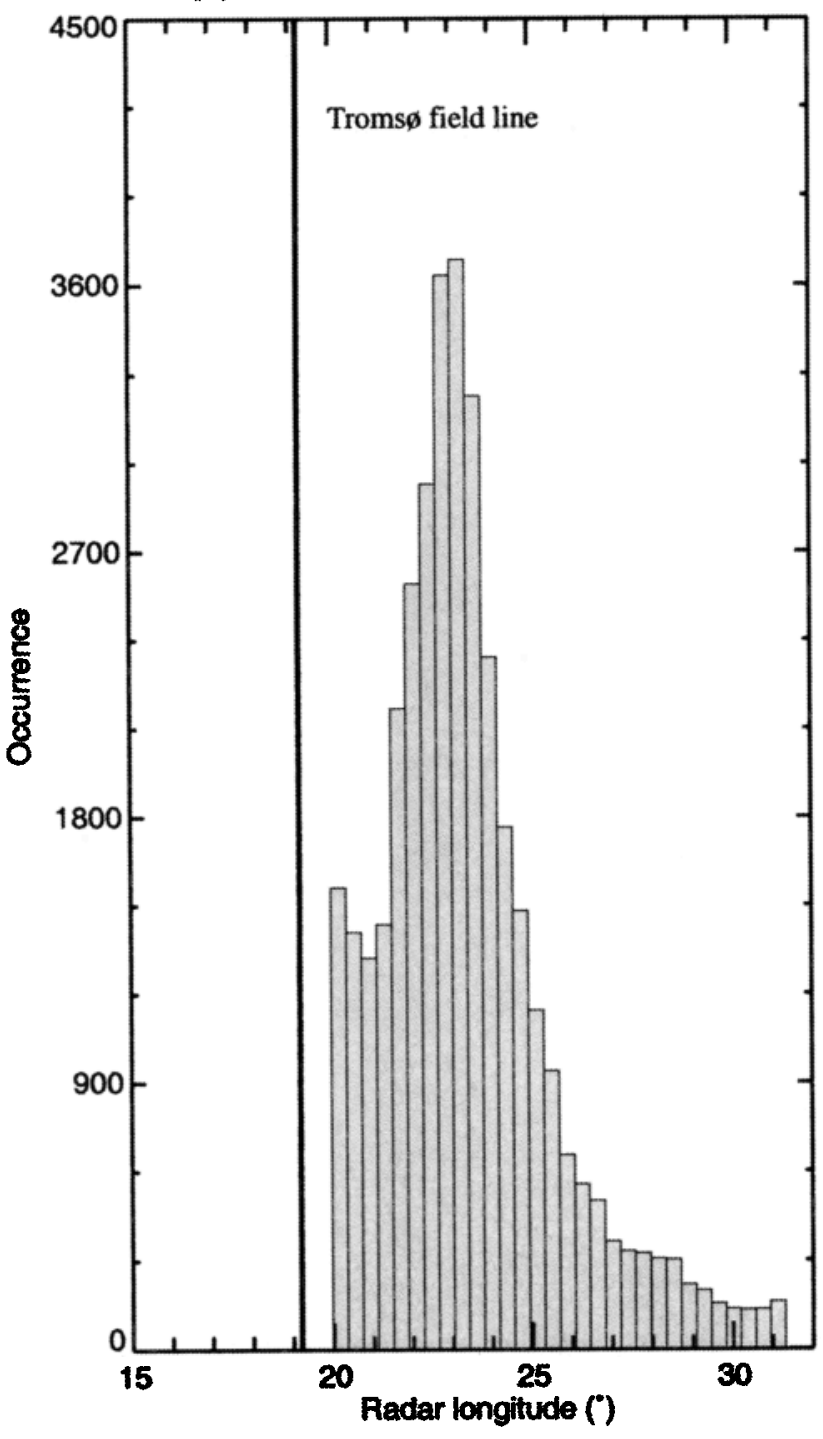

Figure 3. Occurrence rates for artificial backscatter detection at a power of $>10 \mathrm{~dB}$ for Pykkvibær, as a function of radar-deduced longitude. The location of the Troms $\emptyset$ field line ground longitude (the true location of the center of the artificial irregularity patch) is also shown as a solid line. (a) the SP-UK-OUCH run of 1210-1250 UT, October 15, 1998, as shown in Plate 1; (b) the entire 12 hours and 40 min of SP-UK-OUCH data analyzed from Pykkvibær for the years 1998 and 1999.

\subsection{Pykkvibær Radar Performance}

Statistical results from the Pykkvibær radar are displayed in Figure 3. Here we do not distinguish between beam swung and field-aligned operations of the heater, as the heater beam swinging is limited to being near-orthogonal to the look direction of beam 15 of Pykkvibær. The occurrence of radar backscatter at power levels above $10 \mathrm{~dB}$ is plotted as a function of geographic longitude derived from the standard radar range finding algorithm, and the actual longitude of the Tromsø field line is also indicated. The field is near orthogonal to the radar look direction, so the altitude variation of the field line position does not need to be considered in this case. Figure $3 a$ presents the Pykkvibær radar occurrence statistics for the interval displayed in Plate 1. The ground scatter clutter is visible, along with two distinct regions of structured artificial 


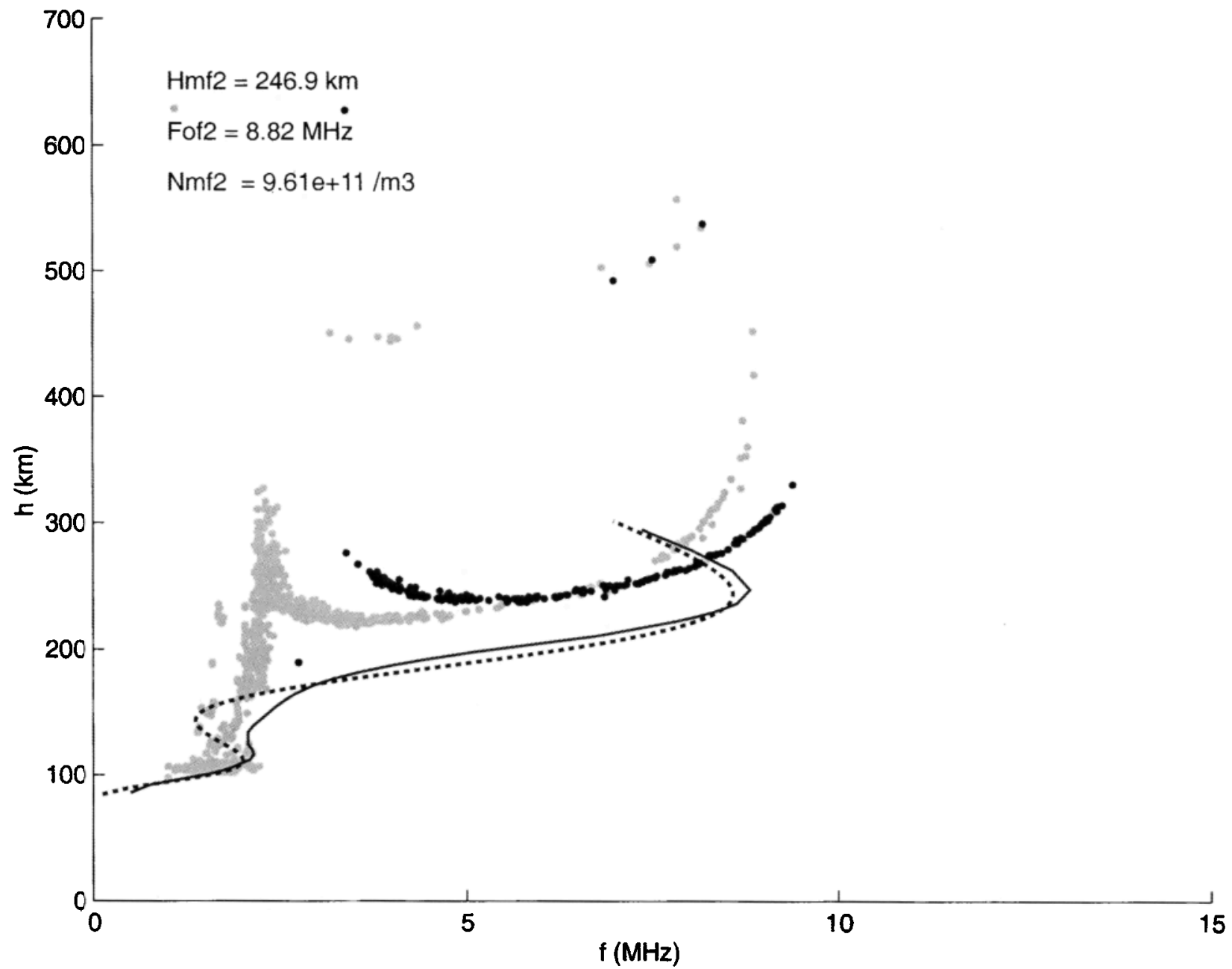

Figure 4. Range $h$ as a function of sounding frequency $f$ measured by the EISCAT dynasonde at Troms $\emptyset$ at 1248 UT on October 15, 1998. O-mode echoes are plotted as grey circles, and X-mode echoes are plotted as solid circles. The solid black curve indicates the real height profile as calculated by the Polan inversion algorithm. The profile parameters are indicated in the top left-hand corner of the plot. The dashed curve illustrates the modeled double-Chapman-layer profile utilized for the ray tracing presented in this paper. The model ionospheric parameters are given in Table 2.

backscatter, the main heater signature being located at apparent longitudes of $22^{\circ}-23^{\circ} \mathrm{E}$, and the farther range scatter being located at apparent longitudes of $29^{\circ}-30^{\circ} \mathrm{E}$. The entire data set is plotted in Figure $3 b$, showing a peak occurrence at $23^{\circ} \mathrm{E}$, where over 3600 datapoints have been accumulated.

\subsection{Ray-tracing Simulation}

In order to gain a more detailed understanding of the propagation conditions prevailing during the experiment of October 15 1998, a ray-tracing simulation has been undertaken. A modified version of the ray-tracing code developed by Jones and Stephenson [1975] has been used in which the angle between the $k$ vector and the magnetic field has been used to identify regions where backscatter is likely to occur in the presence of density irregularities. An example ionogram from the Troms $\emptyset$ dynasonde is illustrated in Figure 4, together with a real height profile, as calculated by the Polan inversion algorithm, and the two- $\alpha$-Chapman-layer model which was used in the ray-tracing simulation. The critical frequencies of the two layers have been determined from the ionosonde measurements, and the ionospheric parameters for the two $\alpha$-Chapman layers employed in the simulation are given in Table 2. The critical and scale heights of the layers have also been chosen to be in 
Table 2. Ionospheric Parameters Used in the Ray Tracing Simulation

\begin{tabular}{cccc}
\hline Region & Critical Frequency, MHz & Critical Height, km & Scale Height, km \\
\hline$E$ & 2.0 & 110 & 10 \\
$F$ & 8.5 & 244 & 35 \\
\hline
\end{tabular}

broad agreement with the values returned by the International Reference Ionosphere (IRI) [Bilitza, 1990]. It should be noted that although we have assumed that the density profile remains fixed with position, this assumption is not unreasonable since the particular interval under study lies around local noon, and the values of $\mathrm{f}_{0} \mathrm{~F}_{2}$ observed by the Troms $\emptyset$ ionosonde are remarkably stable for the entire period. Launch angles for the rays were chosen within $1^{\circ}$ of the mean elevation angles measured by the radars, with ray-trace frequencies of $19.5 \mathrm{MHz}$ chosen for Hankasalmi and $12.2 \mathrm{MHz}$ for Pykkvibær, near the centers of the narrow radaroperating-frequency bands. It was assumed that the backscattered power would return to the radar on the same path as on the outward leg (i.e., reciprocity is assumed to hold). The results obtained from the raytracing simulation of three propagation paths (one from Hankasalmi-Troms $\varnothing$ and two from Pykkvibær-Troms $\varnothing$ ) are presented in Plate 2. For the case of the Hankasalmi radar, orthogonality occurs just prior to reflection while for the Pykkvibær radar orthogonality takes place close to or at the reflection point.

\section{Discussion}

Artificial coherent HF radar backscatter generated by the EISCAT ionospheric heating facility at Troms $\emptyset$ has provided a high-power signature at a known ground range which can be used to calibrate the range assessment of the SuperDARN radar facilities. Case study and statistical analysis of runs of the SP-UKOUCH experiment have provided a database to assess both the accuracy and variability of the standard SuperDARN range-finding algorithm. Here the data presented above will be compared with ray-tracing results to assess the propagation paths concerned. Three regions of structured artificial backscatter (one measured by the Hankasalmi radar and two measured by the Pykkvibær radar) are analyzed in terms of three propagation paths: direct ionospheric backscatter from the Hankasalmi-Troms $\varnothing$ path (hereafter referred to as the $1 / 2$-hop path), ionospheric backscatter from a $1^{1 / 2}$-hop mode across the Pykkvibær-Troms $\emptyset$ path (hereafter referred to as the $1 \frac{1 / 2}{2}$-hop path), and ionospheric backscatter from a $2^{1 / 2}$-hop mode across the PykkvibærTroms $\emptyset$ path (hereafter referred to as the $2^{1 /}{ }^{1}$-hop path).

\subsection{Half-Hop Path Propagation}

The artificial scatter observed from the Hankasalmi radar presented in Plate 1 and Figure 2 resulted from a radar frequency of $19 \mathrm{MHz}$, with a heater interaction height of $210 \mathrm{~km}$ and with radar elevation angles of $\sim 10^{\circ}$. A ray trace for this situation is presented in Plate 2a. The HF rays achieve the orthogonality required for HF backscatter at ground ranges of $\sim 850 \mathrm{~km}$, prior to reflection, and hence the propagation path for this scatter can be determined with confidence. The ground range, the calculated group path, and the measured radar slant range for the three propagation paths are summarized in Table 3. The field-aligned data from Figure $2 b$ are used for this comparison, as this is the most appropriate mode for this purpose, with the heater beam aligned with the Troms $\varnothing$ field line. In this case the strongest heating effects (due to field-aligned heating [Robinson, 1989]) will occur in a very well defined location. The ray trace reveals a difference between the ground range and the group path for this mode of $50 \mathrm{~km}$ and a difference between the measured radar slant range and the calculated group path of only $1.6 \mathrm{~km}$ (radar slant range here has a resolution of $15 \mathrm{~km}$ ). The range-finding algorithm then calculates the backscatter ground latitude at $69.06^{\circ}$. This agrees with the known ground latitude of the Troms $\varnothing$ heater interaction height at $210 \mathrm{~km}$ altitude within $16 \mathrm{~km}$, in practice an accuracy of one $15 \mathrm{~km}$ range gate, well within the $45 \mathrm{~km}$ range gates used in standard radar operations. Comparing the field-aligned heater measurements in Figure $2 b$ with the measurements resulting from heater beam-swinging operations in Figure 2a, the beam swinging can be seen to result in a broader patch of heater-induced irregularities, which are centered between a location vertically above the heater (the center of the heater beam swinging) and the field-aligned position where heating is at its most effective. 


\begin{tabular}{lllllllllll}
$f(\mathrm{MHz})$ & 10.0 & 9.0 & 8.0 & 7.0 & 6.0 & 5.0 & 4.0 & 3.0 & 2.0 & 1.0 \\
\hline
\end{tabular}
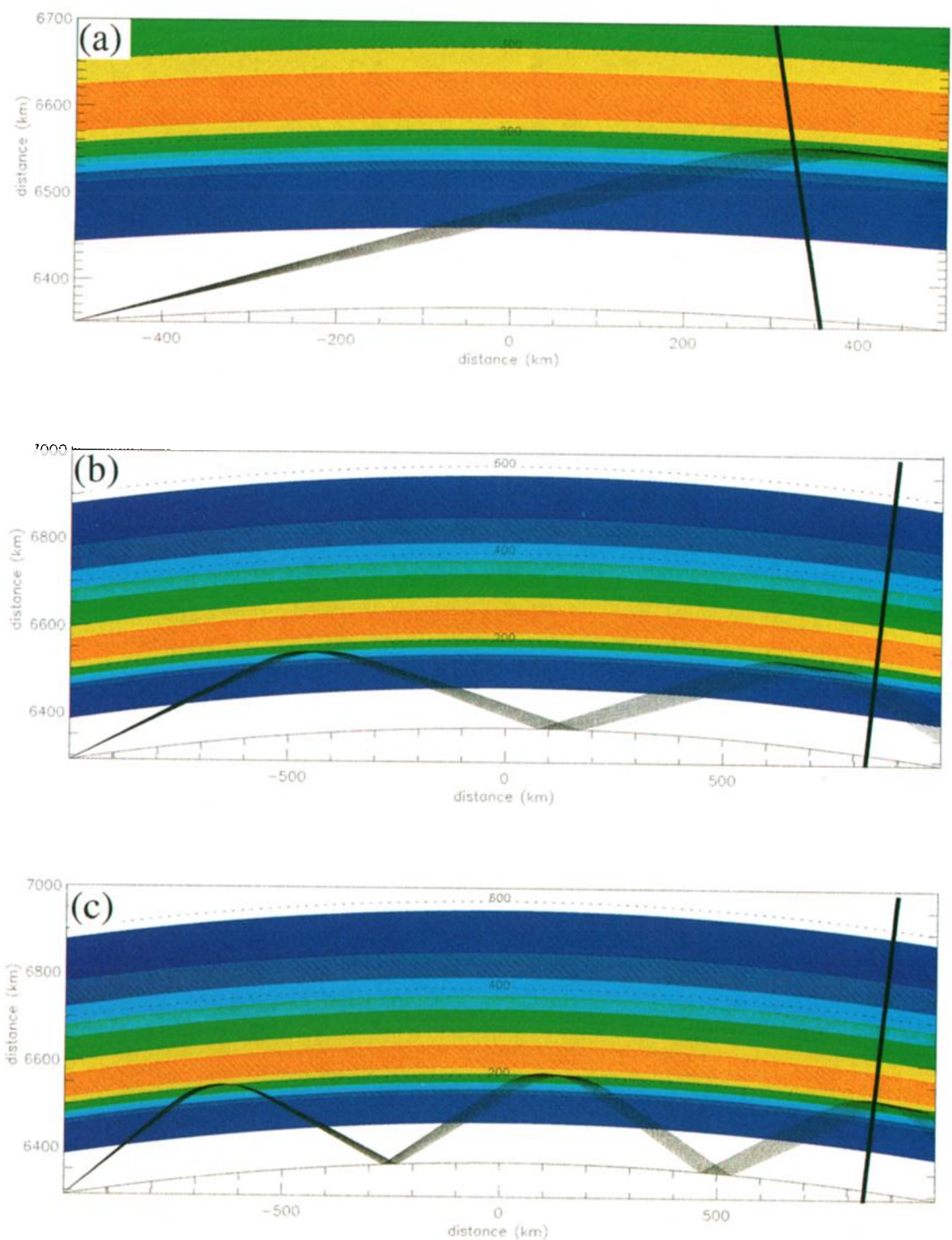

Plate 2. Ray traces [Jones and Stephenson, 1975] for the three HF propagation paths under analysis: (a) the ${ }^{1 / \tau} \tau$ hop path from Hankasalmi to Troms $\emptyset$ at elevation angles $9^{\circ}-11^{\circ}$; (b) the $11^{1 / 2}$ hop path from Pykkvibær to Troms $\varnothing$ at elevation angles $17^{\circ}-19^{\circ}$; and (c) the $2^{1}{ }_{T}$ hop path from Pykkvibær to Troms $\varnothing$ at elevation angles $30^{\circ}-32^{\circ}$. The location of the Troms $\varnothing$ file line is also indicated in each panel. Ray tracing was calculated for frequencies of $19.5 \mathrm{MHz}$ for Hankasalmi and $12.2 \mathrm{MHz}$ for Pykkvibær, near the centers of the narrow radaroperating-frequency bands. 
Table 3. Details of the Calculated and Measured Ray Paths to the center of the Artificial Scatter Region at Troms $\emptyset$, at an Assumed Radar Backscatter Altitude of $210 \mathrm{~km}$

\begin{tabular}{ccccccccc}
\hline Path & $\begin{array}{c}\text { Raytrace } \\
\text { Height, } \\
\mathrm{km}\end{array}$ & $\begin{array}{c}\text { Ground } \\
\text { Range } \\
(\mathrm{GR}), \mathrm{km}\end{array}$ & $\begin{array}{c}\text { Calculated } \\
\text { Group Path } \\
(\mathrm{GP}), \mathrm{km}\end{array}$ & $\begin{array}{c}\text { Measured } \\
\text { Slant Range } \\
\text { (SR), km }\end{array}$ & $\begin{array}{c}\text { GP-GR, } \\
\mathbf{k m}\end{array}$ & $\begin{array}{c}\text { SR-GP, } \\
\mathrm{km}\end{array}$ & $\begin{array}{c}\text { Radar-Deduced } \\
\text { Lat/ Long. }\end{array}$ & $\begin{array}{c}\text { Radar } \\
\text { Range } \\
\text { Error, km }\end{array}$ \\
\hline $\begin{array}{c}\text { Hankasalmi, } \\
10^{\circ} \text { elevation } \\
\text { Pykkvibar, } \\
18^{\circ} \text { elevation }\end{array}$ & 198 & 825.4 & 8754 & 877 & 50 & 1.6 & $69.06^{\circ} \pm 0.13^{\circ}$ & $16 \pm 15$ \\
$\begin{array}{c}\text { Pykkvibar, } \\
31^{\circ} \text { elevation }\end{array}$ & 199 & 1829 & 1986 & 1987 & 157 & 1 & $22.2^{\circ} \pm 0.4^{\circ}$ & $114 \pm 15$ \\
\hline
\end{tabular}

\subsection{One-and-One-Half-Hop Path Propagation}

The main band of artificial scatter observed from the Pykkvibær radar presented in Plate 1 and Figure 3 resulted from a radar frequency of $12 \mathrm{MHz}$, with radar elevation angles of $\sim 18^{\circ}$. A ray trace for this situation is presented in Plate $2 \mathrm{~b}$. The $\mathrm{HF}$ rays achieve orthogonality at ground ranges of $\sim 1800 \mathrm{~km}$, and thus the propagation path for this scatter can again be determined with confidence (the rays also achieve orthogonality at their $1 / 2$-hop position, but this lies outside the radar field of view in this case). The parameters deduced for this propagation path and the data presented in Figure 3a are summarized in Table 3. The raytrace reveals a difference between the ground range and the calculated group path for this mode of 157 $\mathrm{km}$ and a difference between the measured radar slant range and the group path of only $1 \mathrm{~km}$. The rangefinding algorithm then calculates the backscatter ground longitude at $22.2^{\circ}$. This differs from the known ground longitude of the Troms $\varnothing$ heater by $114 \mathrm{~km}$, an accuracy of seven $15 \mathrm{~km}$ range gates, or just over two $45 \mathrm{~km}$ range gates as used in standard radar operations.

\subsection{Two-and-One-Half-Hop Path Propagation}

The second population of artificial scatter observed from the Pykkvibær radar at farther range gates was observed with radar elevation angles of $\sim 31^{\circ}$. A ray trace for this situation is presented in Plate $2 \mathrm{c}$. The HF rays again achieve orthogonality at ground ranges of $\sim 1800 \mathrm{~km}$, and thus the propagation path for this scatter can again be determined with confidence. The parameters deduced for this propagation path are summarized in Table 3 . The ray trace reveals a difference between the ground range and the calculated group path for this mode of $380 \mathrm{~km}$ and a difference between the measured radar slant range and the calculated group path of $67 \mathrm{~km}$. The latter discrepancy results from accumulated errors in the ray trace calculation and inaccuracies in the (uniform) ionospheric models employed. The range-finding algorithm then calculates the backscatter ground longitude at $29.5^{\circ}$. This differs from the known ground longitude of the Troms $\varnothing$ heater by $390 \mathrm{~km}$, an accuracy of twenty-six 15 $\mathrm{km}$ range gates, or eight $45 \mathrm{~km}$ range gates, as used in standard radar operations.

\subsection{Implications for Radar Operations}

The comparison presented in Sections 4.1-4.3 shows an excellent agreement between the calculated ray trace results and the measured radar slant range. This gives confidence in the accuracy of the model ionospheres employed and the propagation modes inferred. It also demonstrates the accuracy of the radar elevation angle determination. The comparison between the known target ground location and the ground location inferred from the range-finding algorithm can then be used to evaluate the performance of the algorithm under more general conditions. For the $1 / 2$-hop path over a ground range of $825 \mathrm{~km}$ the range-finding algorithm has an accuracy of well within the standard $45 \mathrm{~km}$ range gate of a SuperDARN radar. In fact, the accuracy of the range finding over such a path is close to the narrowest range gate such systems are capable of at present. The HF propagation to the point of backscatter under these conditions at $19 \mathrm{MHz}$ is close to straight line propagation, so this result is perhaps unsurprising. The agreement between the ground range and radar range within $\sim 15 \mathrm{~km}$ is fully in accord with the results of Ruohoniemi et al. [1987], who employed a ray-tracing analysis and a velocity field cross-correlation technique between the Goose Bay HF radar and the Sondrestrom incoherent scatter facility for a $1500 \mathrm{~km}^{1 / 2}$-hop path. It also confirms the results of André et al. [1997], who performed a similar velocity field analysis to determine the relative accuracies of various $\mathrm{HF}$ radar frequencies 
over a 1/2-hop path, again finding an accuracy of $15 \mathrm{~km}$. André et al. [1997] suggested an optimum assumed height for $1 / 2$-hop propagation paths of $200-300 \mathrm{~km}$, which is in accord with the results presented here.

For the $1 \frac{1}{1 / 2}$-hop path over $1830 \mathrm{~km}$ an overestimate of the radar range of $\sim 100 \mathrm{~km}$ is deduced as a consequence of the group path of the HF rays exceeding that of the straight line propagation assumed in the range-finding algorithm. In the standard use of the range-finding algorithm, a height of $300-400 \mathrm{~km}$ is assumed to offset the expected difference between the group path and ground range. This altitude leads to a reduced range offset, $60 \mathrm{~km}$. The results presented here suggest that an additional offset of $\sim 60 \mathrm{~km}$ (or an assumed height of 500 $\mathrm{km}$ ) would improve the performance further for $1 \frac{1 / 2}{2}$-hop backscatter.

The $2^{1 /}{ }^{1}$-hop path exhibits even more significant range errors, with the range-finding algorithm overestimating the length of the $1830 \mathrm{~km}$ path by $390 \mathrm{~km}$. In contrast to the $1 \frac{1}{1}{ }^{2}$-hop path no simple adjustment of the assumed backscatter height can be employed to compensate for the range offset, with the adoption of an assumed target altitude of $500 \mathrm{~km}$ only reducing the range offset to 300 $\mathrm{km}$. Two-and-one-half-hop paths are not observed in natural scatter, because of their low power, so this is not in practice a problem for standard radar operations. It does, however, suggest that care should be taken in the use of high-elevation-angle scatter. Baker and Greenwald [1988] demonstrated a relative range error of $120 \mathrm{~km}$ between $15^{\circ}$ and $>20^{\circ}$ elevation angle backscatter, with ionospheric tilts thought to be responsible for the different propagation paths observed. The artificial backscatter data presented in Figures 2 and 3 are extremely consistent, suggesting that the range offsets determined here are highly systematic. No detectable variation is seen in the location of the artificial backscatter in the Hankasalmi field of view, over the 850 $\mathrm{km}, 1 / 2$-hop path. A variability of only two $15 \mathrm{~km}$ range gates is seen in the $1830 \mathrm{~km}, 1^{1 / 2}$-hop path from Pykkvibær to Tromsø. This stability in the measured range gates of the artificial scatter persists even when the location of naturally occurring ground backscatter varies by at least 20 range gates $(300 \mathrm{~km})$ during 4 hour runs of SP-UK-OUCH, indicating changes in the prevailing ionospheric conditions. This observation offers experimental confirmation of the modeling of André et al. [1997], who suggested a group path change of $<10$ $\mathrm{km}$ due to a change in the altitude of the $\mathrm{F}$ region peak by $50 \mathrm{~km}$. It also demonstrates that the accuracy in radar range is maintained to within $30 \mathrm{~km}$ for $1 \frac{1 / 2}{2}$-hop paths. Thus the accuracy in the determination of the location of the backscatter is only weakly controlled by variations in the ionosphere between the radar and target ionosphere. Under most conditions the use of a full ray tracing analysis based on ionosonde observations or on predictive models of the ionosphere is not required for the range accuracy needed for geophysical interpretation of HF radar data.

\section{Summary}

An evaluation of the absolute range finding accuracy of current routine analysis of the SuperDARN network of over-the-horizon HF radars has been performed, comparing ground range, calculated group path, and measured radar slant range of backscatter artificially excited at a known location by the EISCAT heating facility at Troms $\varnothing$. HF propagation over a ${ }^{1 / 2} 2$-hop path, a $1^{1 / 2}$-hop path, and a $2^{1 / 2}$-hop path has been examined for the first time. The radar slant range and the calculated group paths are in excellent agreement for all three paths. The standard algorithm for backscatter ground range location is found to be accurate to within $16 \mathrm{~km}$ and 114 $\mathrm{km}$ for $1 / 2$-hop and $1 \frac{1}{2}$-hop backscatter, respectively, when using the true backscatter height, and these range offsets are extremely consistent. Using an assumed backscatter height of $200-300 \mathrm{~km}$ for ${ }^{1 / 2} 2$-hop paths thus gives an accurate range determination, to within $\sim 15 \mathrm{~km}$, as suggested by André et al. [1997]. The standard assumption of $400 \mathrm{~km}$ height for far range backscatter reduces the error for $1 \frac{1 / 2}{2}$ hop backscatter to $60 \mathrm{~km}$, but the adoption of an additional range offset of $60 \mathrm{~km}$ (or the adoption of an assumed backscatter altitude of 500 $\mathrm{km})$ seems desirable for $1 \frac{1 / 2}{2}$-hop paths. Two-and-onehalf-hop paths, although not seen in practice, would introduce significant range errors, and suggest that highelevation-angle backscatter should be interpreted with caution.

Acknowledgments. The authors thank the director and staff of EISCAT for the operation of the Troms $\varnothing$ heater facility. EISCAT is an international facility funded collaboratively by the research councils of Finland (SA), France (CNRS), the Federal Republic of Germany (MPG), Japan (NIPR), Norway (NFR), Sweden (NFR), and the United Kingdom (PPARC). The SuperDARN Hankasalmi and Pykkvibær HF radars are deployed and operated by the University of Leicester and funded by the PPARC (grant PPA/R/R/1997/00256), the Finnish Meteorological Institute, and the Swedish Institute for Space Physics. D.M.W. is supported on PPARC grant $\mathrm{PPA} / \mathrm{G} / \mathrm{O} / 1997 / 000254$.

\section{References}

André, R., C. Hanuise, J.-P. Villain, and J.-C. Cerisier, HF radars: Multifrequency study of refraction effects and 
localization of scattering, Radio Sci., 32, 153-168, 1997.

Baker, K. B., and R. A. Greenwald, The vertical angle of arrival of high-frequency signals propagating from Thule to Goose bay, Johns Hopkins APL Tech. Dig., 9, 121-130, 1988.

Baker, K. B., R. A. Greenwald, A. D. M. Walker, P. F. Bythrow, L. J. Zanetti, T. A. Potemra, D. A. Hardy, F. J. Rich, and C. L. Rino, A case study of plasma processes in the dayside cleft, J. Geophys. Res., 9I, 3130-3144, 1986.

Bilitza, D. (Ed.), International Reference Ionosphere 1990, NSSDC 90-22, http://nssdc.gsfc.nasa.gov, Natl. Space Sci. Data Cent., Greenbelt, Md., 1990.

Bond, G. E., T. R. Robinson, P. Eglitis, D. M. Wright, A. J. Stocker, M. T. Rietveld and T. B. Jones, Spatial observations by the CUTLASS coherent scatter radar of ionospheric modification by high power radio waves, Ann. Geophysicae, 15, 1412-1421, 1997.

Eglitis, P., T. R. Robinson, M. T. Rietveld, D. M. Wright and G. E. Bond, The phase speed of artificial irregularities observed by CUTLASS during HF modification of the auroral ionosphere, J. Geophys. Res., 103, 2253-2259, 1998.

Greenwald, R. A., et al., DARN/SuperDARN A global view of the dynamics of high-latitude convection, Space Sci. Rev., $71,761-796,1995$.

Jones, R. M., and J. J. Stephenson, A versatile threedimensional ray tracing computer program for radıo waves in the conosphere, OT 75-76, Off. of Telecommun., U.S. Dep. of Comm., Washington, D.C., 1975.

Lockwood, M., J. Moen, S.W.H. Cowley, A.D. Farmer, U.P. Løvhaug, H. Lühr, and V.N. Davda, Variability of dayside convection and motions of the cusp/cleft aurora, Geophys. Res. Lett., 20, 1011-1014, 1993.

Lockwood, M., S.W.H. Cowley; P.E. Sandholt, and U.P Løvhaug, Causes of plasma flow bursts and dayside auroral transients: An evaluation of two models invoking reconnection pulses and changes in the $\mathrm{Y}$ component of the magnetosheath field, J. Geophys. Res., 100, 7613-7626, 1995.

Milan, S.E., T.K. Yeoman, M. Lester, E.C. Thomas, and T.B. Jones, Initial backscatter occurrence statistics from the CUTLASS HF radars, Ann. Geophysicae, 15, 703-718, 1997.

Milan, S. E., T. K. Yeoman, and M. Lester, The dayside auroral zone as a hard target for coherent HF radars, Geophys. Res. Lett., 25, 3717-3720, 1998.

Milan, S.E., M. Lester, S.W.H. Cowley and M. Brittnacher, Convection and auroral response to a southward turning of the IMF: Polar UVI, CUTLASS, and IMAGE signatures of transient magnetic flux transfer at the magnetopause, J. Geophys. Res., 105, 15,741-15,755, 2000.

Neudegg, D.A., T.K. Yeoman, S.W.H. Cowley, G. Provan, G. Haerendel, W. Baumjohann, U. Auster, K.-H. Fornacon, E. Georgescu, and C. J. Owen, A Flux transfer event observed at the magnetopause by the Equator-S spacecraft and in the ionosphere by the CUTLASS HF radar, Ann. Geophysicae, 17, 707-711, 1999.

Pinnock, M., A.S. Rodger, J.R. Dudeney, K.B. Baker, P.T. Newell, R.A. Greenwald, and M. Greenspan, Observations of an enhanced convection channel in the cusp ionosphere, J. Geophys. Res., 98, 3767-3776, 1993.

Pinnock, M., A.S. Rodger, J.R. Dudeney, F. Rich, and K.B. Baker, High spatial and temporal resolution observations of the ionospheric cusp, Ann. Geophysicae, 13, 919-925, 1995.

Provan, G., T.K. Yeoman, and S.E. Milan, CUTLASS Finland radar observations of the ionospheric signatures of flux transfer events and the resulting plasma flows, Ann. Geophysicae, 16, 1411-1422, 1998.

Provan, G., T.K. Yeoman, and S.W.H. Cowley, The influence of the IMF $B_{y}$ component on the location of pulsed flows in the dayside ionosphere observed by an HF radar, Geophys. Res. Lett., 26, 521-524, 1999.

Rietveld, M. T., H. Kohl, H. Kopka and P. Stubbe, Introduction to ionospheric heating at Troms $\varnothing$, I, Experimental overview, J. Atmos. Terr. Phys., 55, 577-599, 1993.

Robinson, T. R., The heating of the high latitude ionosphere by high power radio waves, Phys. Rep., 179, 79-209, 1989.

Robinson, T. R., A. J. Stocker, G. E. Bond, P. Eglitis, D. M. Wright and T. B. Jones, $\mathrm{O}$ - and $\mathrm{X}$-mode heating effects observed simultaneously with the CUTLASS and EISCAT radars and low power HF diagnostics at Troms $\varnothing$, Ann. Geophysicae, 15, 134-136, 1997.

Ruohoniemi, J. M., R. A. Greenwald, K. B. Baker, J.-P. Villain, and M. A. McCready, Drift motions of small-scale irregularities in the high-latıtude $F$ region: An experımental comparison with plasma drift motions, J. Geophys. Res., 92, 4553-4564, 1987.

Sandholt, P.E., C.J. Farrugia, P. Stauning, S.W.H. Cowley, and T. Hansen, Cusp/cleft auroral forms and activities in relation to ionospheric convection: Responses to specific changes in solar wind and interplanetary magnetic field conditions, $J$. Geophys. Res., 101, 5003-5020, 1996.

Villain, J.-P., R. A. Greenwald, and J. F. Vickrey, HF ray tracing at high latitudes using measured meridional electron density distributions, Radio Sci., 19, 359-374, 1984.

Wright, D. M., and T. K. Yeoman, High resolution bistatic HF radar observations of ULF waves in artificially generated backscatter, Geophys. Res. Lett., 26, 2825-2828, 1999.

T. B. Jones, A. J. Stocker, D. M. Wright, and T. K. Yeoman, Department of Physics and Astronomy, University of Leicester, University Road, Leicester, LE1 7RH, England, U. K. (tim.yeoman@1on.le.ac.uk)

(Received September 11, 2000; revised November 27, 2000; accepted February 21, 2001.)

Copyright 2001 by the American Geophysical Unıon. 